\title{
Insecticidal effects of eudesmanes from Pluchea sagittalis (Asteraceae) on Spodoptera frugiperda and Ceratitis capitata
}

\author{
A. Sosa ${ }^{1}$, M. Costa $^{1}$, A. Salvatore ${ }^{4}$, A. Bardon ${ }^{1,3}$, S. Borkosky ${ }^{1}$, N. Vera ${ }^{2 *}$ \\ ${ }^{1}$ Instituto de Química Orgánica, ${ }^{2}$ Instituto de Estudios Farmacológicos, ${ }^{3}$ INQUINOA-CONICET, Facultad de Bioquímica, \\ Química y Farmacia, UNT, Phone: 54-381-4247752, Ayacucho 471 (4000), Tucumán, Argentina \\ ${ }^{4}$ Facultad de Agronomia y Zootecnia, UNT, Phone: 54-0381-4364147, Florentino Ameghino s/n. B ${ }^{\circ}$ Mercantil. Campo \\ Experimental (4105), El Manantial, Tucumán, Argentina \\ *Correspondence: N. Vera. Facultad de Bioquímica, Química y Farmacia. Universidad Nacional de Tucumán. Ayacucho 471.
}

Tucumán (4000).

\begin{abstract}
Eudesmanoids play an important role in the protection of plants against herbivores. Pluchea sagittalis (Lamarck) Cabrera (Asteraceae) is widespread in tropical South America and contains compounds that provide protection against phytophagous insects. In the present work we isolated seven sesquiterpenoids with eudesmane skeletons that were evaluated for their insecticidal activities against Spodoptera frugiperda and Ceratitis capitata, pests that cause serious damage to crops in the Argentine northwest. The Eudesmanes were incorporated at different concentrations to the diet of Spodoptera frugiperda. In the choice test, larval feeding behavior was altered. The eudesmanes 1, 5 and 7 showed the highest activity with feeding election indexes (FEI) of 50, 50, and $72 \%$, respectively at $200 \mu \mathrm{g} / \mathrm{g}$ of diet. When tested for insecticidal activity using neonate larvae with the nochoice artificial diet bioassays, eudesmane 1 was the most toxic in the larval stage ( $L D_{50} 177.80 \mathrm{mg} / \mathrm{g}$ of diet). Compounds 5 lowered the percentage of adult emergence and produced the most malformations (72\%) compared with control. Drastic effects were observed in the oviposition deterrence activity against $C$. capitata. The maximum oviposition deterrence (87\%) was recorded with eudesmane 5 at dose $30 \mu \mathrm{g} / \mathrm{cm}^{2}$ of artificial fruit. Finally, eudesmanes 6 and 7 showed significant larval and pupal mortality against the first generation larvae of viable eggs oviposited by females fed with the treated diet $(100 \mu \mathrm{g} / \mathrm{g}$ artificial diet $)$.
\end{abstract}

Keywords - sesquiterpenoids, antifeedant, insect growth regulation, oviposition deterrence.

\section{INTRODUCTION}

It is well accepted that plant natural products may constitute new sources of insect pest control. The species belonging to the genus Pluchea (Asteraceae) consist of approximately 90 herbaceous species that grow in several countries of South America, i.e. Paraguay, Argentina and Brazil (Bremer \& Anderberg 1994). Previous chemical investigations of the genus have shown the presence of eudesmane-type sesquiterpenoids (Ahmad et al. 1990; 1991; Guilhon \& Müller 1996; 1998 a,b; Mahmoud 1997) as well as monoterpenes, lignan glycosides, triterpenoids, (Chakravarty \& Mukhopadhyay 1994) and flavonoids (Ahmed et al. 1987; Scholz et al. 1994). Pluchea sagittalis (Lam.) Cabrera is popularly known as "Lucera," "Yerba Lucero" or "Quitoc. Pharmacological studies demonstrated that aqueous and dichloromethane extracts obtained from $P$. sagittalis have a wide spectrum of anti-inflammatory, antioxidant (Pérez-Garcia et al. 1996; 2001), antinociceptive and gastroprotective activities (Figueredo $e t$ al. 2011). Nevertheless, there is little information about their action on insects. Insecticidal and antifeeding effects have been reported for other sesquiterpenes against different insect species (Wang et al. 1991; Gonzalez et al. 1993; Dadang et al. 1996). The results of previous works by Céspedes et al. (2001) and Alarcon et al. (2013) reported feeding deterrent and insecticidal activities of certain eudesmane-type sesquiterpenoids against $S$. frugiperda (Lepidoptera: Noctuidae) larvae and Drosophila melanogaster, respectively. In a previous paper, we reported the isolation and identification of twelve eudesmane-type sesquiterpenoids from a Bolivian collection of $P$. sagittalis, together with their antifeedant activity at $100 \mu \mathrm{g} / \mathrm{g}$ of diet against $S$. frugiperda, under chosen conditions (Vera et al. 2008).

Objectives of the present study were to evaluate the insecticidal activity and sublethal effects of eudesmanes isolated from $P$. sagittalis against fall armyworm $S$. frugiperda and Ceratitis capitata (Wiedemann) (Diptera 
Tephritidae), known as mediterranean fruit fly. For both insect pests, the bioassays were conducted under laboratory conditions.

\section{MATERIALS AND METHODS}

Plants and compounds.

P. sagittalis (Lamarck) Cabrera was collected at the flowering stage in December of 2013 in Tarija, Bolivia. Structures of tested compounds are shown in Figure 1. Compounds 1-7 were isolated from aerial parts of the plant and were purified in sufficient amount to be used in the bioassays. Identification of the eudesmanes 1-7 was accomplished by spectroscopic methods (IR, ${ }^{1} \mathrm{H}-\mathrm{NMR},{ }^{13} \mathrm{C}$ NMR, and MS) and direct comparison with authentic samples (Vera et al. 2008). Previous to the bioassays, purity of eudesmanes was checked by HPLC (Gilson with a differential refractometer, Middleton, USA) in Beckman $\mathrm{C} 18$ and $\mathrm{C} 8$ columns ( $250 \times 10 \mathrm{~mm}$ i.d., $5 \mu \mathrm{m}$ particle size), using $\mathrm{MeOH}: \mathrm{H}_{2} \mathrm{O}$ mixtures as eluents.

\section{Bioassays}

\section{Insect rearing}

S. frugiperda larvae were obtained from our laboratory population. The larval diet consisted of a mixture of yeast (3 $\mathrm{g})$, boiled and milled bean (250 g), wheat germ (12.5 g), agar agar (12.5 g), ascorbic acid (1.5 g), methyl phydroxybenzoate $(1.5 \mathrm{~g})$, formaldehyde $(4 \mathrm{ml}$ of a $38 \%$ water solution), and water $(500 \mathrm{ml})$.

The colony of $C$. capitata used in the bioassays was derived from the laboratory of the Estación Experimental Agroindustrial Obispo Colombres (EEAOC). It was initiated with pupae of infested fruits obtained from northwestern Argentina cultivating oranges. Adults were fed on a diet prepared with an aqueous solution of a mixture of sucrose and hydrolyzed protein (3: 1 ratio). The brood chamber was maintained at $24 \pm 2{ }^{\circ} \mathrm{C}, 60 \pm 10 \%$ relative humidity and a photoperiod of 12L: 12D.

\section{Antifeedant test against $S$. frugiperda (Choice test)}

Antifeedant tests against $S$. frugiperda larvae were carried out as follows (Vera et al. 2008). A portion of artificial diet was mixed with acetone and, after solvent removal in vacuum this portion was employed as control diet. Another portion was mixed with an acetone solution of each test compound, in order to reach 25, 50, 100 and $200 \mu \mathrm{g} / \mathrm{g}$ of treatment per $\mathrm{g}$ of diet. After solvent evaporation, control and treated diets were placed in test tubes (20 replicates) in which third instars larvae were placed between both portions of diet to be kept at $27^{\circ} \mathrm{C}$ and $60 \pm 15 \%$ relative humidity. When $50 \%$ of control diet had been eaten, control and treated diets were removed from the tubes and weighted www.ijeab.com accurately. To evaluate the feeding behavior a "Feeding election index" was calculated as FEI $=(1-\mathrm{T} / \mathrm{C}) 100$, where $\mathrm{C}$ and $\mathrm{T}$ represent the amounts of control and treated diets eaten, respectively.

\section{Antifeedant test against $S$. frugiperda (No choice Test)}

A portion of artificial diet was mixed with acetone and, after solvent removal in vacuum; this portion was employed as control diet. Another portion was mixed with an acetone solution of each test compound (treatment), in order to reach $25,50,100$ and $200 \mu \mathrm{g} / \mathrm{g}$ of treatment per g of diet. After solvent evaporation, control diet was placed in a test tube and a larva was introduced. The same amount of treated diet was placed in a different test tube with a larva inside. Larvae were allowed to eat an after the $50 \%$ of control diet had been eaten, control and treated diets were removed from the tubes and weighted accurately. The experiment was carried out in 20 replicates. To evaluate the feeding behavior under no choice conditions, the FEI was calculated (Vera et al. 2006).

\section{Insecticidal bioassay against $S$. frugiperda}

The insecticidal bioassay activity against larvae of $S$ frugiperda was carried out as follows (Vera et al. 2006). Control and treated diets were placed in different test tubes (20 replicates for treated and 20 for control experiments) in which 2 nd instar larvae were placed to be kept at $27{ }^{\circ} \mathrm{C}$ and $60 \pm 15 \%$ relative humidity until emergency of the 1 st generation of adults. Larval developmental periods as well as mortality rates were recorded for treatments containing eudesmanes (25, 50, 100 and $200 \mu \mathrm{g} / \mathrm{g}$ of diet) and control experiments. The larval period duration (days), larval and pupal mortality percentage and the number of malformed adults were registered.

\section{Food consumption and utilisation}

Ten days after the beginning of the experiment, the larval weight and diet eated were determined again, in order to record the relative consumption rate (RCR), relative growth rate (RGR), efficiency of conversion of ingested food (ECI), efficiency of conversion of digested food (ECD) and approximate digestibility (AD) during the early larval instars (Waldbauer 1968; Farrar et al. 1989). The developmental indices were calculated as follows:

$\mathrm{RCR}=\mathrm{I} / \mathrm{BaT}$

$\mathrm{RGR}=\mathrm{DB} / \mathrm{BaT}$

$\mathrm{ECI}=(\mathrm{DB} / \mathrm{I}) * 100$

$\mathrm{AD}=[(\mathrm{I}) \mathrm{F}) / \mathrm{I}] * 100$

$\mathrm{ECD}=[\mathrm{DB} /(\mathrm{I}) \mathrm{F})] * 100$

where

I = weight of food consumed; 
$\mathrm{Ba}=$ arithmetic mean of insect weight during the experiment $1 / 4$

[(PF-PI)/log (PF/PI)];

$\mathrm{PF}=$ larvae final weight $(\mathrm{mg})$;

$\mathrm{PI}=$ larvae starting weight $(\mathrm{mg})$;

$\mathrm{T}=$ feeding period in days;

$\mathrm{DB}=$ change in body weight;

$\mathrm{F}=$ weight of faeces produced during the feeding period

\section{Oviposition-Deterrent test}

Artificial fruits (oviposition substrates) were prepared by boiling a mixture of peach juice $(500 \mathrm{ml})$, agar $(15 \mathrm{~g})$, and sodium benzoate (one teaspoonful) as preservative. This agar solution was poured into cylindrical molds, allowed to gel, and sliced. The agar cylinders were then wrapped in PVC film to avoid dehydration. The surface of the wrapped cylinder was pricked with a needle and treated with an acetone or methanol solution of the sample to be tested. An amount of $30 \mu \mathrm{g} / \mathrm{cm}^{2}$ of the test compound was deposited. Control cylinders were impregnated only with the solvent that was then removed in vacuum. Three groups of $C$. capitata adults were selected from the EEAOC laboratory colony. Each group, consisting of seven male-female pairs, was placed in a small cage and covered with voile (a light, almost transparent cloth made of silk). Two agar cylinders (sample and control) were placed over the voile, and females oviposited on one or the other according to their preference (Fig. 2). After 4 days, eggs were gently rinsed from the agar and counted.

The oviposition index was defined as IO\% $=(1-\mathrm{T} / \mathrm{C}) \times 100$, where $\mathrm{T}$ is the number of eggs laid in the treated artificial fruit, and $\mathrm{C}$ is the number of eggs deposited in the control fruit (Socolsky et al. 2008).

\section{Insecticidal bioassay with $C$. capitata adult flies}

Assays were performed by adding compounds to artificial diet of the adult flies at a concentration of $100 \mu \mathrm{g} / \mathrm{g}$ (sample weight / weight of artificial diet). This diet is offered to adult flies (F1) of C. capitata (300 flies per trial). They are kept in cages until seen 2 days after the beginning of intercourse and then are allowed to oviposit.

In this assay were evaluated:

1- The volume of oviposited eggs.

2- The viability of eggs.

3- The mortality of adult flies.

4- The larval mortality F2 (1st generation of neonates from parents subjected to treatment).

5- The pupal mortality F2.

The experiment was performed in triplicate, using an identical but without the addition of substances, as a target system. The experience takes place at a controlled www.ijeab.com temperature $\left(24 \pm 2{ }^{\circ} \mathrm{C}\right)$ and r.h. $(60 \pm 10)$ and photoperiod L12:D12 (Salvatore et al. 2004).

Statistical analysis

The results are reported as mean \pm SEM. The differences in the mean values were evaluated by analysis of variance (ANOVA). The Tukey test was used for all pair wise multiple comparisons of groups. In all statistical analysis, $\mathrm{P}$ $>0.05$ was considered not significant. The $\mathrm{LD}_{50}$ values for each activity were calculated using a probit analysis software program based on percentage of mortality obtained at each concentration of the samples (MINITAB Release 14 for Windows).

\section{RESULTS}

During our screening program on biological activities of plants from Argentine and Bolivia in a preliminary trial (Vera et al. 2008), the eudesmanes of $P$. sagittalis displayed antifeedant activity at $100 \mu \mathrm{g} / \mathrm{g}$ of diet on S. frugiperda. Based on this information, we carried out several studies with eudesmanes $\mathbf{1}$ - 7 (Figure 1), in a concentration range $25-200 \mu \mathrm{g} / \mathrm{g}$ of diet.

\section{Antifeedant activity}

The antifeedant activities of eudesmanes 1-7 against $S$. frugiperda are shown in Table 1. S. frugiperda larvae ate significantly less when fed a diet treated with compounds $\mathbf{1}$, 5 and 7 at $200 \mu \mathrm{g} / \mathrm{g}$ of diet (Feeding election indexes FEI, of 50, 50, and $72 \%$, respectively). Eudesmane 5, was the only one with an inhibition percentage higher than $25 \%$ at the lowest dose tested $25 \mu \mathrm{g} / \mathrm{g}$ diet. All eudesmanes have a concentration dependent deterrent activity. In the no-choice feeding assay none of the tested compounds displayed antifeedant effects against $S$. frugiperda (Table 1).

\section{Insecticidal bioassay against $S$. frugiperda}

A significant growth reduction was observed in the larvae fed on the treated diet containing eudesmanes 1-3, 5 and 7, even at the lowest concentration. Growth inhibition of about $60 \%$ relative to control, was observed in the treatment with compound 7 at all the concentrations tested (Table 3). A marked decrease in the daily consumption of diet was observed in treatments with eudesmanes 1, 3, 5 and 7 at the four concentrations tested. At doses of $100 \mu \mathrm{g}$ and 200 $\mu \mathrm{g} / \mathrm{g}$, diet intake inhibition percentage reached $85 \%$ relative to control. A significant reduction $(\mathrm{P}<0.01)$ in ECI and ECD was also observed in the compounds at 100 and 200 $\mu \mathrm{g} / \mathrm{g}$ except for eudesmanes $\mathbf{4}$ and $\mathbf{6}$ that showed no significant differences compared to control. No significant differences $(\mathrm{P}<0.01)$ on DA were observed in any of the eudesmanes at $100 \mu \mathrm{g} / \mathrm{g}$ of diet (Table 2). 
The larvae were fed during the course of the experiment. Eudesmanes 1-7 were incorporated to the larval diet at 25$200 \mu \mathrm{g} / \mathrm{g}$ and larval development and mortality were recorded. Our results are outlined in Table 2. Eudesmane 1 was the most toxic in the larval stage with $57 \%$ larval mortality at $200 \mu \mathrm{g} / \mathrm{g}$ of diet. Products $\mathbf{1}$ and $\mathbf{5}$ also showed high percentages of pupal mortality with 33 and $30 \%$, respectively, at the highest dose tested $(200 \mathrm{mg} / \mathrm{g} \mathrm{diet})$. Adult insects that survived the treatment showed higher rates of malformation. Compound $\mathbf{5}$ was the most active at $200 \mu \mathrm{g} / \mathrm{g}$ diet with a $50 \%$ of malformation in the wings which prevented them from reproducing. Also, the duration of larval and pupal cycle, compared to that of the control, were affected by the treatments at doses of 100 and 200 $\mu \mathrm{g} / \mathrm{g}$ of diet (Table 3).

\section{Oviposition Deterrent test}

The results are summarized in Table 4. All tested compounds (1-7) produced oviposition deterrence. At a dose $30 \mu \mathrm{g} / \mathrm{cm}^{2}$ of artificial fruit the eudesmanes $\mathbf{1}$ and $\mathbf{5}$ were the most active with percentages of 84.18 and 87.52 of inhibition, respectively. (Table 4)

\subsection{Insecticidal bioassay with $C$. capitata adult flies}

Only the major eudesmanes (6 and 7) were evaluated. As shown in Table 5, the treatments did not produce mortality in adult insects that ingested the treated diet. The viability of oviposited eggs by females who ingested treatments was not affected. However, higher percentages of F2 neonate larvae mortality were observed (F2: the first generation larvae of viable eggs oviposited by females consuming the treated diet), $51 \%$ for eudesmane 6 and $54 \%$ for eudesmane 7 at $100 \mu \mathrm{g} / \mathrm{g}$ artificial diet. F2 pupal mortality was 33 and $29 \%$ for 6 and 7 respectively (Table 5).

\section{DISCUSSION}

Botanicals are a rich source of organic chemicals on earth. Discovery of novel toxins and/or antifeedants from plant extracts has been recently emphasized as a potential method for the development of ecologically safe pesticides (Wheeler et al. 2001). Antifeedants offer first line of crop protection against notorious insects. Any substance that reduces food consumption by an insect can be considered as an antifeedant or feeding deterrent (Isman 2002). In general, antifeedants have profound adverse effects on insect feeding behavior (Hummelbrunner LA \& Isman MB). Antifeedants can be described as allomone substances which inhibit feeding and do not kill the insect pests directly, but rather limit its developmental potential considerably and act as a phagodeterrent or phagorepellent over test as well as permanent insect pests feeding on the plant (Lakshmanan et al. 2012). Plant substances acting as antifeedants are found www.ijeab.com in all the compound groups of secondary plant metabolism. However, the most effective insect feeding inhibitors come from terpenoids, alkaloids, saponins and polyphenols (Koul 2005). In a previous study carried out by our group, we determined that sesquiterpenes eudesmane-type produced a significant deterrence of the intake in Spodoptera frugiperda larvae when the diet choice tests were performed at $100 \mu \mathrm{g} / \mathrm{g}$ diet (Vera et al. 2008). The results of our bioassays showed that eudesmanes 1-7 produced inhibition of feeding in a concentration range between $25-200 \mu \mathrm{g} / \mathrm{g}$ of diet and the effect is concentration dependent for all eudesmanes tested in the choice test. Compound 7 was the most active, reaching a value of inhibition at $200 \mu \mathrm{g} / \mathrm{g}$ of diet seven times greater than the one at $25 \mu \mathrm{g} / \mathrm{g}$ of diet. However, when evaluating the feeding behavior of the insect without giving it the choice, we observed that none of the eudesmanes inhibited the insect from feeding, even at the highest dose used $(200 \mu \mathrm{g} / \mathrm{g}$ diet $)$. This difference in dietary behavior may be due to a suppressive effect of food where the reduction of food intake occurs after initial consumption. Similar results were presented by Macleod et al. (1990), who used two active ingredients isolated from M. azedarach (meliatoxin A2 and meliatoxin B1), which inhibited feeding when the larvae of Spodoptera litura were able to choose. However, in tests without this option Meliatoxin B1 did not reduce the intake. Other extracts also showed increased anti-food activity on S. littoralis, when the caterpillars had access to the control over non-choice trials (Sadek 2003).

The nutritional indices help us to be able to approach the mode of action of these compounds. The EUs 1, 3, 5 and 7 produced a significant reduction in larval growth (RGR) even at $25 \mu \mathrm{g} / \mathrm{g}$ diet. In relation to consumption, there is a marked decrease in RCR for treatments with EUs 1, 3, 5 and 7 at all doses evaluated. A significant reduction in ECI and ECD were observed for all compounds at 100 and 200 $\mu \mathrm{g} / \mathrm{g}$, except for EUs 4 and 6 that did not show significant differences with the control (table 2). Energy diversion to other metabolic pathways, such as those involved in the detoxification of allelochemicals, may be the cause of the decrease in efficiencies (Koul \& Isman 1991; Hernández \& Vendramim 1997). This decrease causes inhibition of larval growth and is considered as a chronic post-ingestive toxic effect (Wheeler \& Isman 2001; Sadek 2003) by several authors. As the diet concentration of the EUs increases, feed intake, growth and feed conversion efficiency reduction were observed suggesting that these compounds have a toxic effect on $S$. frugiperda, producing larval, pupal mortality and high percentages of malformations in adults. 
The EUs 18 and 21 produced the greatest Ceratitis capitata inhibition of oviposition with\% IO of 84 and $88 \%$, respectively. That is to say, these substances caused a reduction of more than $80 \%$ in the number of eggs deposited in the treated artificial fruit in comparison with the artificial fruit control. These compounds exhibit an activity similar to naringin, isolated from Elaphoglossum spathulatum $\left(\mathrm{IO}=74 \%, 6 \mu \mathrm{g} / \mathrm{cm}^{2}\right)$, one of the natural products evaluated in our work group that produced the greatest inhibition of oviposition in $C$. capitata (Socolsky 2003), which would be promising for the control of this pest. These results constitute the first antecedent of the study of EUs as inhibitors of oviposition in C. capitata.

Although the number of tested eudesmanes was reduced to establish a relationship between structure and biological activity, our results show how small structural changes may modify the mode of action of these compounds. Eudesmanes that had a hydroperoxide (5) or formoxi groups in their structures ( $\mathbf{1}$ and $\mathbf{7}$ ) were the most active, while the eudesmanes possessing an acetyl group in position 4 lost such activity noticeably. Additionally, an $\alpha, \beta$-unsaturated system played an important role in antifeedant activity, as seen when comparing compound $\mathbf{2}$ with compound $\mathbf{3}$, that showed a low activity (Table 1). These results are in agreement with those published in previous works by other authors and our research group (Srivastava et al. 1990; .Faini et al. 1997; Vera et al. 2008; Alarcon et al. 2013). Eudesmanes highly oxygenated has a marked influence on biological activity and the individual biological activities of sesquiterpenoids depend on the different functional groups present and the pattern of oxygenation. Similar results were published by Gonzalez et al. (1993); Céspedes et al. (2001); Guan et al. (2005); and Alarcon et al. (2013). All eudesmanes assayed have trans-fused decalin architecture differently from the sesquiterpenes used by Miyazawa et al. (2000) and Alarcon et al. (2013). The sites and mode of action of these compounds are being investigated and probably correspond to a combination of antifeedant action, as well as insecticidal and insect growth regulation activities. Although some natural insecticides are found on the market, the search for new compounds with activity against a variety of insects are always necessary either to prevent the emergence of resistance in insects or to guarantee the ready availability of natural insecticides through more widely distributed sources. This study suggests that eudesmanes and plants containing it might be used as new tools for protecting from harmful insects, especially in organic agriculture. Additionally, these compounds could be promising precursors to generate a series of more active derivatives that acted as a chemical defense against predation by certain phytophagous insects.

Conflict of interest

The authors declare that there are no conflicts of interest and they have no actual or potential competing financial interests

\section{ACKNOWLEDGMENTS}

Work in Argentina was supported by grants from Agencia Nacional de Promoción Científica y Tecnológica (ANPCyT), Consejo Nacional de Investigaciones Científicas y Técnicas de Argentina (CONICET) and Consejo de Investigaciones de la Universidad Nacional de Tucumán (CIUNT).

\section{REFERENCES}

[1] AlARCON, J., LAMILLA, C. \& CESPEDES, C.L. (2013). Insecticidal activity of sesquiterpenes skeleton synthesized by the conventional Robinson annulations reaction on Drosophila melanogaster. Industrial Crops and Products 42, 268-272.

[2] AHMAD, V.U., SULTANA, A. \& FIZZA, K.Z. (1990). Two new terpenoids from Pluchea arguta. Zeitschrift für Naturforschung 45B, 385-388.

[3] AHMAD, V.U., FIZZA, K.Z., KHAN, M.A. \& FAROOQUI, T.A. (1991). Sesquiterpenes from Pluchea arguta. Phytochemistry 30, 689-691.

[4] AHMED AA, MELEK FR \& MABRY TJ (1987). Sulfated and non-sulfated flavonoids from Pluchea dioscoridis. Journal of Natural products 50, 311.

[5] BREMER, K. \& ANDERBERG, A. (1994). Asteraceae: cladistics \& classification. Portland, Or.: Timber Press.

[6] CÉSPEDES, C.L., ALARCÓN, J., ARANDA, E., BECERRA, J. \& SILVA, M. (2001). Insect growth regulator and insecticidal activity of $\beta$ dihydroagarofurans from Maytenus spp. (Celastraceae). Zeitschrift für Naturforschung C 56c, 603-613.

[7] CHAKRAVARTY, A.K. \& MUKHOPADHYAY, S. (1994). New thiophene derivatives from Pluchea indica. Indian Journal of Chemistry 33B, 978-980.

[8] DADANG OHSAWA, K., KATO, S. \& YAMAMOTO, I. (1996). Insecticidal compound in tuber of Cyperus rotundus L. against the diamondback moth larvae. Journal of Pest Science 21, 444-446.

[9] FAINI, F., LABBE, C., TORRES, R., DELLE MONACHE, G., DELLE MONACHE, F. \& COLL, J. (1997). Eudesmane derivatives from Flourensia 
thurifera: structure and biological activity. Natural

Products Letters 11, 1-4.

[10] FARRAR, R.R., BARBOUR, J.D. \& KENEDY, G.G. (1989). Quantifying food consumption and growth in insects. Annales of the Entomological Society of America 82, 593-598.

[11]FIGUEREDO, S.M., PINTO DO NASCIMENTO, F., FREITAS, C.S., HATSUKO BAGGIO, C., SOLDI, C., PIZZOLATTI, M.G., CHELLION DE IBARROLA, M., DEGEN DE ARRUA, R.L. \& SOARES SANTOS, A.R. (2011). Antinociceptive and gastroprotective actions of ethanolic extract from Pluchea sagittalis (Lam) Cabrera. Journal of Ethnopharmacology 135, 603-609.

[12] GONZALEZ, A., JIMENEZ, I.A., RAVELO, A.G, \& BAZZOCHI, I.L. (1993). Minor sesquiterpenes from Maytenus canariensis with insecticidal and antifeedant activity. Tetrahedron 49, 6637-6644.

[13] GUAN, Y.K., LI, P., FANG, L.F. \& LI, Y.L. (2005). The first total synthesis of 3-oxo-11,12,13trihydroxyeudesm-4-ene. Chinese Chemical Letters 16, 711-712.

[14] GUILHON， G.M.S.P. \& MÜLLER， A.H. (1996) Eudesmane derivatives from Pluchea quitoc. Phytochemistry 43, 417-421.

[15] GUILHON, G.M.S.P. \& MÜLLER, A.H. (1998a). Eudesmane sesquiterpenoids from Pluchea quitoc. Phytochemistry 47, 227-229.

[16] GUILHON, G.M.S.P. \& MÜLLER, A.H. (1998b). Eudesmanolides and epoxycuauthemones from Pluchea quitoc. Phytochemistry 49, 1347-1351.

[17] HERNANDEZ, C. R. \& VENDRAMIN, J.D. (1997). Bioactivity evaluation of aqueous extracts of Meliaceae to Spodoptera frugiperda. Revista agrícola 72, 305-318.

[18] HUMMELBRUNNER, L.A. \& ISMAN, M.B. (2001). Acute, sublethal, antifeedant and synergestic effects of monoterpenoid essential oil compounds on the tobacco cutworm Spodoptera litura (Lepidoptera: Noctudiae). Journal of Agricultural and Food Chemistry 49, 715720.

[19] ISMAN, M.B. (2002). Insect antifeedants. Pesticide Outlook 13,152-157.

[20] KOUL, O. (2005). Insect Antifeedants. CRC Press LLC: Boca Raton, FL, USA.

[21] KOUL, O. \& ISMAN, M. B. (1991). Effects of azadirachtin on the dietary utilization and development of the variegated cutworm Peridroma saucia. Journal of Insect Physiology 37, 591-598.

[22] LAKSHMANAN, S., KRISHNAPPA, K. \& ELUMALAI, K. (2012). Certain plant essential oils www.ijeab.com against antifeedant activity of Spodoptera litura (Fab.), Helicoverpa armigera (Hub.) and Achaea janata (Linn.) (Lepidoptera: Noctuidae). International Journal of Current Life Sciences 2, 5-11.

[23] MACLEOD, J. K., MOELLER, P. D., MOLINSKI, T. F. \& KOUL, O. (1990). Antifeedant activity against $b$ larvae and [13C] NMR spectral assignments of the meliatoxins. Journal of Chemical Ecology 16, 25112518.

[24] MAHMOUD, A. (1997). 7-epi-eudesmanes, eudesmanoic acids, eudesmanolides and other sesquiterpenes from Pluchea dioscoridis. Phytochemistry 45, 1633-1688.

[25] MIYAZAWA, M., NAKAMURA, Y. \& ISHIKAWA, Y. (2000). Insecticidal sesquiterpene from Alpinia oxyphylla against Drosophila melanogaster. Journal of Agricultural and Food Chemistry 48, 3639-3641.

[26] PEREZ-GARCÍA, F., MARÍN, E., CAÑIGUERAL, S. \& ADZET, T. (1996) Anti-inflammatory action of Pluchea sagittalis: involvement of an antioxidant mechanism. Life Sciences 59, 2033-2040.

[27] PEREZ-GARCÍA, F., MARÍN, E., PARELLA, T., ADZET, T. \& CAÑIGUERAL, S. (2005). Activity of taraxasteryl acetate on inflammation and heat shock protein synthesis. Phytomedicine 12, 278-284.

[28] SADEK, M.M. (2003). Antifeedant and toxic activity of Adhatoda vasica leaf extract against Spodoptera littoralis (Lep. Noctuidae). Journal of Applied Entomology 127, 396-404.

[29] SALVATORE, A., BORKOSKY, S., WILLINK, E. \& BARDÓN, A. (2004). Toxic effects of lemon peel constituents on Ceratitis capitata. Journal of Chemical Ecology 30, 323-333.

[30] SCHOLZ, E., HEINRICH, M. \& HUNKLER, D. (1994). Caffeoylquinic acids and some biological activities of Pluchea symphytifolia. Planta Medica 60 , 360-364.

[31] SOCOLSKY, C., SALVATORE, A., ASAKAWA, Y. \& BARDÓN, A. (2003). Bioactive new bitter-tasting p-hydroxystyrene glycoside and other constituents from the fern Elaphoglossum spathulatum. Arkivoc 10, 347-355.

[32] SOCOLSKY, C., FASCIO, M.L., D’ACCORSO, N.B., SALVATORE, A., WILLINK, E., ASAKAWA, Y. \& BARDON, A. (2008). Effects of p-Vinylphenyl Glycosides and other related compounds on the oviposition behavior of Ceratitis capitata. Journal of Chemical Ecology 34, 539-548.

[33] SRIVASTAVA, R.P., PROKSCH, P. \& WRAY, V. (1990). Toxicity and antifeedant activity of a

Page 366 
sesquiterpene lactone from Encelia against Spodoptera littoralis. Phytochemistry 29, 3445-3448.

[34] VERA, N., POPICH, S., LUNA, L., CRAVERO, R., GONZÁLEZ SIERRA, M. \& BARDÓN, A. (2006). Toxicity and synergism in the feeding deterrence of some coumarins on Spodoptera frugiperda Smith (Lepidoptera: Noctuidae). Chemistry \& Biodiversity 3, 21-26.

[35] VERA, N., MISICO, R., GONZALEZ SIERRA, M., ASAKAWA, Y. \& BARDON, A. (2008). Eudesmanes from Pluchea sagittalis. Their antifeedant activity on Spodoptera frugiperda. Phytochemistry 69, 16891694.

[36] WANG, M., QIN, H., KONG, M. \& LI, Y. (1991). Insecticidal sesquiterpene polyol ester from Celastrus angulatus. Phytochemistry 30, 3931-3933.
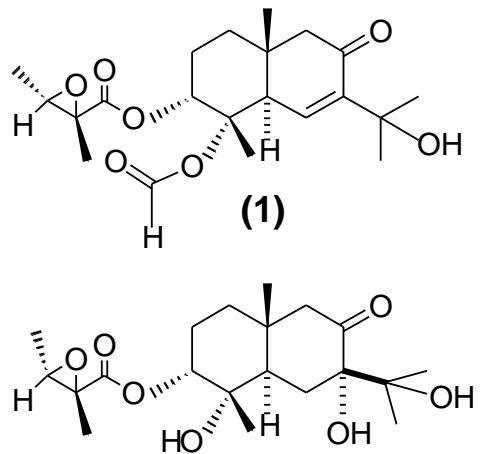

(2)

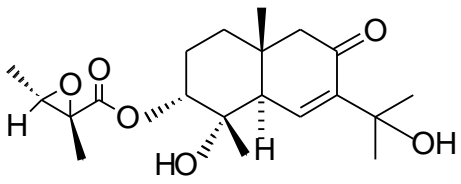

(3)

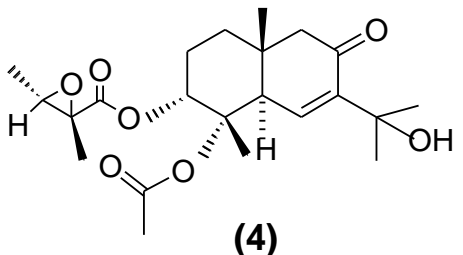

(4)
[37] WALDBAUER, G.P. (1968). The consumption and utilization of food by insects. Advances Insect Physiololy 5, 229-288.

[38] WHEELER, D.A. \& ISMAN, M.B. (2001). Antifeedant and toxic activity of Trichilia americana extract against the larvae of Spodoptera litura. Entomologia Experimentalis et Applicata 98, 9-16.

[39] WHEELER, D.A., ISMAN, M.B., SANCHEZVINDAS, P.E., ARNASON, J.T. (2001). Screening of Costa Rican Trichilia species for biological activity against the larvae of Spodoptera litura (Lepidoptera: Noctuidae). Biochemical Systematic and Ecology 29, 347-358.<smiles>CC(=O)O[C@H]1[C@H]2C=C(C(C)(C)OO)C(=O)C[C@]2(C)CC[C@H]1OC1O[C@@H](C)[C@@H]1C</smiles>

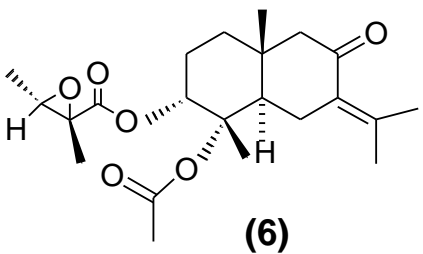

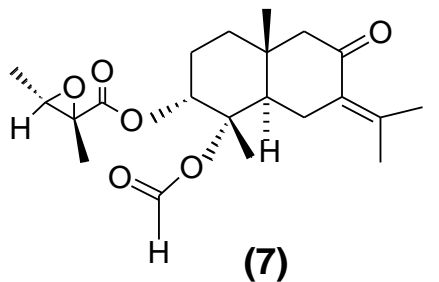

Fig.1: Eudesmanes isolated from Pluchea sagittalis 
Table.1: Insect antifeedant activities of eudesmanes (1-7) on S. frugiperda.

Feeding deterrence index

a) $\% \mathrm{FEI}_{\mathrm{CH}}$ Choice test a) \% $\mathrm{FEI}_{\mathrm{NCH}} \mathrm{No}$ Choice test

50

$30.7 \pm 5.2 \mathrm{~d}$
$13.7 \pm 2.0 \mathrm{a}$
$29.8 \pm 3.8 \mathrm{~b}$
$28.0 \pm 3.6 \mathrm{~b}$
$50.1 \pm 4.1 \mathrm{c}$
$19.2 \pm 2.2 \mathrm{~b}$
$32.3 \pm 4.2 \mathrm{~d}$

\section{$50.4 \pm 5.0 \mathrm{c}$} $17.9 \pm 2.8 \mathrm{~b}$ $34.6 \pm 4.3 \mathrm{~d}$ $37.3 \pm 3.4 \mathrm{~d}$ $50.7 \pm 5.3 \mathrm{c}$ $19.4 \pm 5.0 \mathrm{~b}$ $72.2 \pm 6.7 \mathrm{e}$

$1.0 \pm 0.2 \mathrm{a}$

$1.1 \pm 0.2 \mathrm{a}$

$0.8 \pm 0.1 \mathrm{a}$

$2.4 \pm 0.5 \mathrm{~b}$

$2.2 \pm 0.2 \mathrm{~b}$

$2.9 \pm 0.8 \mathrm{~b}$

$2.5 \pm 0.2 \mathrm{~b}$

\section{$1.0 \pm 0.4 \mathrm{a}$} $2.0 \pm 0.8 \mathrm{~b}$ $3.1 \pm 0.2 \mathrm{bc}$ $3.1 \pm 0.3 \mathrm{bc}$ $1.8 \pm 0.6 \mathrm{ab}$ $3.5 \pm 0.5 \mathrm{c}$ $3.8 \pm 0.6 \mathrm{c}$

100

\begin{tabular}{cc}
$4.0 \pm 0.4 \mathrm{c}$ & $5.4 \pm 0.4 \mathrm{~d}$ \\
$2.0 \pm 0.3 \mathrm{~b}$ & $4.9 \pm 0.8 \mathrm{~d}$ \\
$3.0 \pm 0.4 \mathrm{~b}$ & $4.6 \pm 0.3 \mathrm{~d}$ \\
$7.0 \pm 0.7 \mathrm{e}$ & $7.3 \pm 0.8 \mathrm{de}$ \\
$7.0 \pm 1.0 \mathrm{e}$ & $6.7 \pm 1.6 \mathrm{de}$ \\
$6.0 \pm 1.0 \mathrm{de}$ & $6.4 \pm 1.6 \mathrm{de}$ \\
$5.0 \pm 0.9 \mathrm{~d}$ & $6.2 \pm 1.5 \mathrm{de}$ \\
\hline
\end{tabular}

The values followed by the same letter are not significantly different. The significance level $\mathrm{P}<0.05$. * FEI $(\%)=$ Feeding election index $=[(1-\mathrm{T} / \mathrm{C}) \times 100]$.

Table.2: Effect of eudesmanes (1-7) incorporated into larval diet on food consumption and utilization by $S$. frugiperda larvae.

Nutritional indices

\begin{tabular}{|c|c|c|c|c|c|c|}
\hline Compounds & Doses $(\mu \mathrm{g} / \mathrm{g})$ & a) $\mathbf{R C R}=\mathbf{I} /\left(\mathrm{B}_{\mathbf{a}} \mathrm{T}\right)$ & a) $R G R=\Delta B /\left(B_{a} T\right)$ & a) $E C I=(\Delta B / I * 100)$ & a) $\mathrm{AD}=(\mathrm{I}-\mathrm{F} / \mathrm{I})^{*} \mathbf{1 0 0}$ & a) $\mathrm{ECD}=(\Delta \mathrm{B} / \mathrm{I}-\mathrm{F})^{*} 100$ \\
\hline Control & & $0.51 \pm 0.06 a$ & $0.25 \pm 0.03 a$ & $21.12 \pm 2.9 \mathrm{a}$ & $73.88 \pm 3.5 \mathrm{a}$ & $23.45 \pm 1.5 \mathrm{a}$ \\
\hline 1 & $\begin{array}{c}25 \\
50 \\
100 \\
200\end{array}$ & $\begin{array}{l}0.39 \pm 0.06 \mathbf{b} \\
0.25 \pm 0.05 \mathbf{c} \\
0.14 \pm 0.03 \mathbf{d} \\
0.13 \pm 0.02 \mathbf{d}\end{array}$ & $\begin{array}{l}0.12 \pm 0.03 \mathbf{b} \\
0.11 \pm 0.03 \mathbf{b} \\
0.09 \pm 0.03 \mathbf{b} \\
0.06 \pm 0.06 \mathbf{c}\end{array}$ & $\begin{array}{l}23.13 \pm 1.8 \mathbf{a} \\
18.43 \pm 2.2 \mathbf{b} \\
18.34 \pm 3.8 \mathbf{b} \\
14.38 \pm 2.6 \mathbf{c}\end{array}$ & $\begin{array}{l}73.20 \pm 8.0 \mathbf{a} \\
68.21 \pm 2.6 \mathbf{a} \\
69.26 \pm 1.5 \mathbf{a} \\
67.51 \pm 2.4 \mathbf{a}\end{array}$ & $\begin{array}{l}22.63 \pm 2.2 \mathbf{a} \\
18.44 \pm 2.8 \mathbf{b} \\
17.62 \pm 2.5 \mathbf{b} \\
14.13 \pm 1.8 \mathbf{c}\end{array}$ \\
\hline 2 & $\begin{array}{c}25 \\
50 \\
100 \\
200\end{array}$ & $\begin{array}{l}0.45 \pm 0.03 \mathbf{a} \\
0.44 \pm 0.03 \mathbf{a} \\
0.43 \pm 0.02 \mathbf{a} \\
0.34 \pm 0.04 \mathbf{b}\end{array}$ & $\begin{array}{c}0.09 \pm 0.02 \mathbf{b} \\
0.08 \pm 0.008 \mathbf{d} \\
0.07 \pm 0.01 \mathbf{d} \\
0.08 \pm 0.02 \mathbf{d}\end{array}$ & $\begin{array}{l}20.09 \pm 2.8 \mathbf{a} \\
22.32 \pm 2.5 \mathbf{a} \\
17.78 \pm 2.8 \mathbf{b} \\
17.48 \pm 1.5 \mathbf{b}\end{array}$ & $\begin{array}{l}74.22 \pm 2.3 \mathrm{a} \\
75.64 \pm 3.3 \mathrm{a} \\
71.16 \pm 3.1 \mathrm{a} \\
76.01 \pm 2.2 \mathrm{a}\end{array}$ & $\begin{array}{l}20.09 \pm 2.8 \mathbf{a} \\
22.32 \pm 2.5 \mathbf{a} \\
17.78 \pm 2.8 \mathbf{b} \\
17.48 \pm 1.5 \mathbf{b}\end{array}$ \\
\hline 3 & $\begin{array}{c}25 \\
50 \\
100 \\
200\end{array}$ & $\begin{array}{l}0.29 \pm 0.06 \mathbf{b} \\
0.29 \pm 0.07 \mathbf{b} \\
0.15 \pm 0.02 \mathbf{d} \\
0.15 \pm 0.04 \mathbf{d}\end{array}$ & $\begin{array}{c}0.11 \pm 0.03 \mathbf{b} \\
0.11 \pm 0.02 \mathbf{b} \\
0.04 \pm 0.008 \mathbf{f} \\
0.04 \pm 0.02 \mathbf{c}\end{array}$ & $\begin{array}{l}14.78 \pm 2.6 \mathbf{c} \\
13.88 \pm 1.6 \mathbf{c} \\
12.96 \pm 2.3 \mathbf{c} \\
12.45 \pm 1.8 \mathbf{c}\end{array}$ & $\begin{array}{l}71.13 \pm 6.3 \mathbf{a} \\
78.67 \pm 8.3 \mathbf{a} \\
72.00 \pm 3.1 \mathbf{a} \\
69.91 \pm 4.2 \mathbf{a}\end{array}$ & $\begin{array}{l}13.07 \pm 7.2 \mathbf{c} \\
15.52 \pm 1.2 \mathbf{c} \\
10.12 \pm 3.1 \mathbf{c} \\
10.45 \pm 4.9 \mathbf{c}\end{array}$ \\
\hline 4 & $\begin{array}{c}25 \\
50 \\
100 \\
200\end{array}$ & $\begin{array}{l}0.47 \pm 0.05 \mathbf{a} \\
0.44 \pm 0.06 \mathbf{a} \\
0.42 \pm 0.06 \mathbf{a} \\
0.42 \pm 0.06 \mathbf{a}\end{array}$ & $\begin{array}{l}0.24 \pm 0.04 \mathbf{a} \\
0.23 \pm 0.04 \mathbf{a} \\
0.21 \pm 0.05 \mathbf{a} \\
0.26 \pm 0.05 \mathbf{a}\end{array}$ & $\begin{array}{l}20.58 \pm 1.2 \mathbf{a} \\
22.02 \pm 1.8 \mathbf{a} \\
21.71 \pm 0.7 \mathbf{a} \\
21.51 \pm 1.3 \mathbf{a}\end{array}$ & $\begin{array}{l}69.21 \pm 3.0 \mathbf{a} \\
73.78 \pm 4.2 \mathbf{a} \\
74.16 \pm 0.8 \mathbf{a} \\
73.84 \pm 4.0 \mathbf{a}\end{array}$ & $\begin{array}{l}27.14 \pm 7.2 \mathbf{a} \\
26.96 \pm 3.2 \mathbf{a} \\
24.79 \pm 4.8 \mathbf{a} \\
23.29 \pm 5.9 \mathbf{a}\end{array}$ \\
\hline 5 & $\begin{array}{c}25 \\
50 \\
100 \\
200\end{array}$ & $\begin{array}{l}0.36 \pm 0.03 \mathbf{b} \\
0.34 \pm 0.04 \mathbf{b} \\
0.13 \pm 0.01 \mathbf{d} \\
0.13 \pm 0.03 \mathbf{d}\end{array}$ & $\begin{array}{c}0.06 \pm 0.02 \mathbf{c} \\
0.05 \pm 0.02 \mathbf{c} \\
0.02 \pm 0.007 \mathbf{f} \\
0.05 \pm 0.01 \mathbf{d c}\end{array}$ & $\begin{array}{c}21.32 \pm 0.5 \mathbf{a} \\
18.45 \pm 0.5 \mathbf{b} \\
17.67 \pm 0.4 \mathbf{b} \\
14.65 \pm 0.6 \mathbf{c}\end{array}$ & $\begin{array}{l}75.49 \pm 5.5 \mathbf{a} \\
72.79 \pm 3.1 \mathbf{a} \\
69.21 \pm 2.5 \mathbf{a} \\
71.20 \pm 2.4 \mathbf{a}\end{array}$ & $\begin{array}{l}20.12 \pm 3.3 \mathbf{a} \\
18.53 \pm 5.4 \mathbf{b} \\
18.28 \pm 8.2 \mathbf{b} \\
14.73 \pm 7.1 \mathbf{c}\end{array}$ \\
\hline www.ije & $\begin{array}{c}25 \\
50 \\
100 \\
200 \\
\text { b.com }\end{array}$ & $\begin{array}{c}0.48 \pm 0.05 \mathbf{a} \\
0.42 \pm 0.04 \mathbf{a b} \\
0.43 \pm 0.05 \mathbf{a b} \\
0.41 \pm 2.1 \mathbf{b}\end{array}$ & $\begin{array}{l}0.29 \pm 0.04 \mathbf{a} \\
0.24 \pm 0.01 \mathbf{a} \\
0.24 \pm 0.02 \mathbf{a} \\
0.25 \pm 0.02 \mathbf{a}\end{array}$ & $\begin{array}{l}20.58 \pm 1.2 \mathbf{a} \\
22.02 \pm 0.8 \mathbf{a} \\
20.71 \pm 0.7 \mathbf{a} \\
21.31 \pm 1.3 \mathbf{a}\end{array}$ & $\begin{array}{l}71.58 \pm 8.0 \mathbf{a} \\
74.16 \pm 5.2 \mathbf{a} \\
78.83 \pm 7.2 \mathbf{a} \\
76.64 \pm 2.0 \mathbf{a}\end{array}$ & $\begin{array}{r}20.27 \pm 4.2 \mathbf{a} \\
22.61 \pm 4.2 \mathbf{a} \\
23.52 \pm 5.3 \mathbf{a} \\
19.80 \pm 2.9 \mathrm{a} \\
\text { Page } \mid \mathbf{3 6 8}\end{array}$ \\
\hline
\end{tabular}


7

$\begin{array}{cc}25 & 0.38 \pm 0.05 \mathbf{b} \\ 50 & 0.39 \pm 0.04 \mathbf{b} \\ 100 & 0.40 \pm 0.03 \mathbf{b} \\ 200 & 0.40 \pm 0.04 \mathbf{b}\end{array}$

$0.14 \pm 0.02 \mathbf{b}$

$0.15 \pm 0.01 \mathbf{b}$

$0.15 \pm 0.02 \mathbf{b}$ $0.14 \pm 0.03$ bc
$16.17 \pm 1.4 \mathbf{b}$

$15.70 \pm 0.3 \mathbf{b}$

$12.64 \pm 0.8 \mathbf{c}$ $11.93 \pm 1.8 \mathbf{c}$
$77.01 \pm 4.9$ a

$75.40 \pm 6.1 \mathbf{a}$

$75.55 \pm 2.5$ a

$78.20 \pm 4.4 \mathbf{a}$
$18.12 \pm 4.3 \mathbf{a b}$ $18.65 \pm 7.1 \mathbf{a b}$ $13.67 \pm 5.4 \mathrm{~b}$ $12.78 \pm 4.4 \mathbf{b}$

Values are mean $\pm \operatorname{SE}(n=20)$. The values followed by the same letter are not significantly different. The significance level $P<$ 0.05 .

Table.4: Effect of eudesmanes (1-7) on the oviposition-behavior of C. capitata

\begin{tabular}{|c|c|c|c|}
\hline Compounds & $\begin{array}{l}\text { Number of Eggs Laid on the } \\
\text { Control Fruit }\end{array}$ & $\begin{array}{c}\text { Number of Eggs Laid on the } \\
\text { Treated Fruit }\end{array}$ & $\begin{array}{c}\% \mathrm{IO}=(1-\mathrm{T} / \mathrm{C}) \\
30 \mu \mathrm{g} / \mathrm{cm}^{2}\end{array}$ \\
\hline $1^{*}$ & $810 \pm 43 a$ & $256 \pm 40 \mathrm{a}$ & $84.18 \pm 13.1 \mathrm{a}$ \\
\hline $2 *$ & $741 \pm 25 a$ & $254 \pm 27 b$ & $59.96 \pm 7.5 b$ \\
\hline $3^{*}$ & $876 \pm 12 \mathrm{a}$ & $670 \pm 14 c$ & $34.85 \pm 1.1 \mathrm{c}$ \\
\hline 4 & $457 \pm 31 \mathrm{a}$ & $411 \pm 34 d$ & $11.2 \pm 2.0 \mathrm{~d}$ \\
\hline $5^{*}$ & $522 \pm 51 \mathrm{a}$ & $91 \pm 4^{\mathrm{a}}$ & $87,52 \pm 5.5 \mathrm{a}$ \\
\hline 6 & $868 \pm 23 a$ & $753 \pm 14 d$ & $13.2 \pm 3.0 \mathrm{~d}$ \\
\hline 7 & $894 \pm 11 a$ & $488 \pm 13^{a}$ & $45.4 \pm 4.0 \mathrm{a}$ \\
\hline
\end{tabular}

Numbers represent mean \pm SEM, $n=3$. Means within a column followed by the same letter are not significantly different $(P>0.05$, paired $\mathrm{t}$ test)

Table.5: Insecticidal activity of eudesmanes (6 and 7) against adults of Ceratitis capitata.

Mortality F1 (\%) Oviposition of F1 Hatching eggs of F1 Larval Mortality of F2

Volume of eggs $\left.(\mathbf{m l})^{a}\right)$

Control

5 a

$1.2 \pm 0.1 \mathrm{a}$

$0.4 \pm 0.05 b$

$0.4 \pm 0.1 b$
$(\%)$

94 a

$95 \mathrm{a}$

96 a
(\%)

$12 \mathrm{a}$

$51 b$

$54 b$
Pupal Mortality of F2 (\%)

$11 \mathrm{a}$

$33 b$

$39 b$

F1: Adult insects fed on the treated diet. F2: The first generation larvae of viable eggs oviposited by females consuming the treated diet.

Numbers represent mean \pm SEM, $n=3$. Means within a column followed by the same letter are not significantly different $(\mathrm{P}>0.05$, paired $\mathrm{t}$ test) 